\title{
Thermal and Mass Spectroscopic Analysis of BF and BOF Sludges: Study of Their Behavior under Air and Inert Atmosphere
}

\author{
Mamdouh Omran ${ }^{1,2, *(\mathbb{D}}$, Timo Fabritius ${ }^{1}\left(\mathbb{D}\right.$, Yaowei $\mathrm{Yu}^{2}$ and Guo Chen ${ }^{3, *}$ \\ 1 Process Metallurgy Research Group, Faculty of Technology, University of Oulu, 90014 Oulu, Finland; \\ timo.fabritius@oulu.fi \\ 2 State Key Laboratory of Advanced Special Steel, School of Materials Science and Engineering, \\ Shanghai University, Shanghai 201900, China; yaowei.yu@hotmail.com \\ 3 Key Laboratory of Green-Chemistry Materials in University of Yunnan Province, Kunming Key Laboratory \\ of Energy Materials Chemistry, Yunnan Minzu University, Kunming 650500, China \\ * Correspondence: amdouh.omran@oulu.fi (M.O.); guochen@kmust.edu.cn (G.C.); \\ Tel.: +358449183230 (M.O.); Tel.: +86-15925113721 (G.C.)
}

Received: 22 February 2020; Accepted: 17 March 2020; Published: 19 March 2020

\begin{abstract}
Differential thermal analysis (DTA), thermogravimetry (TG), and mass spectrometry (MS) were used to study the thermal behavior of the blast furnace (BF) and basic oxygen furnace (BOF) sludges generated from the iron-making industry. The results indicated that under air atmosphere the two types of sludge are different in their thermal behavior. In BF sludge, the exothermic carbon gasification $\left(\mathrm{CO} / \mathrm{CO}_{2}\right)$ reaction dominated the process, while in BOF sludge, the significant reaction occurred at $755^{\circ} \mathrm{C}$ and was associated with a slight mass gain owing to the partial oxidation of $\mathrm{Fe}_{3} \mathrm{O}_{4}$ to $\mathrm{Fe}_{2} \mathrm{O}_{3}$. Under inert atmosphere, the thermal behavior of both $\mathrm{BF}$ and $\mathrm{BOF}$ sludges were dominated by a reduction reaction. In BF sludge, the endothermic reactions ranged from 785 to $1115^{\circ} \mathrm{C}$ due to the reduction of iron oxides as follows: $\mathrm{Fe}_{2} \mathrm{O}_{3} \rightarrow \mathrm{Fe}_{3} \mathrm{O}_{4} \rightarrow \mathrm{FeO} \rightarrow \mathrm{Fe}$. A total mass loss of about $27.78 \%$ was observed in the TG curve. While in BOF sludge, the endothermic peaks corresponded to magnetite reduction to iron (Fe). The overall mass loss of the BOF was approximately $16.92 \%$. The mass spectrum of gases evolution for both $\mathrm{BF}$ and $\mathrm{BOF}$ sludges revealed that $\mathrm{CO} / \mathrm{CO}_{2}$ gases were released from the sludges.
\end{abstract}

Keywords: BF sludge; BOF sludge; thermal analysis; mass spectra

\section{Introduction}

Basic oxygen furnace $(\mathrm{BOF})$ and blast furnace $(\mathrm{BF})$ sludges are fine wastes produced from the iron and steel industry [1,2]. BF sludge is a by-product generated from the treatment of flue gas during pig iron production in blast furnaces [1,2], while BOF sludge is generated in converter-based steel mills [3]. BF sludge consists of fine-grained materials containing substantial quantities of valuable elements (iron oxides and coke), in addition to minor heavy metals such as zinc, lead, and cadmium [4,5]. The mineralogical composition of $\mathrm{BF}$ and $\mathrm{BOF}$ sludges consist mostly of iron oxide (hematite, $\mathrm{Fe}_{2} \mathrm{O}_{3}$, and magnetite, $\mathrm{Fe}_{3} \mathrm{O}_{4}$ ) and coke. The sludges also contain calcium carbonate, calcium magnesium carbonate, iron carbonate, and silica oxide phases [6].

$\mathrm{BF}$ and BOF sludges are generated at the SSAB Raahe plant in Finland during the production of liquid steel through the BF-BOF manufacture line. The approximate quantity of BF sludge and BOF sludge created at the plant is about 60,000 ton per year/dry basis [7]. Up to 500,000 tons of BF sludge has been generated each year in the European steel industry in the past several decades $[5,8]$. In some cases, the sludge contains toxic cyanide (CN) and mercury (Hg) compounds [9,10]. Landfill 
is the conventional method of sludge disposal. Numerous methods have been proposed for sludge utilization. The comprehensive characterization of the sludge is a crucial step in defining the most suitable recycling strategy [8].

This paper is part of a project which focuses on the characterization and exploitation of BF and BOF sludges. The aim of this work is to put together a detailed examination on the thermal behavior of BOF and BF sludges. Differential thermal analysis (DTA), thermogravimetry (TG), and mass spectroscopy (MS) were used to determine the thermal behavior of the sludge under air and inert atmosphere. The thermal reactions and mass loss during these reactions were determined by DTA-TG. The gases which evolved from the sludge during experiments were detected with MS.

\section{Materials and Methods}

\subsection{Sample Preparation}

Representative BF and BOF sludge samples were received from the SSAB Raahe plant, Raahe, Finland.

The sludge was dried according to the BS EN 1097-5:2008 standard. The sample was dried in a lab drying oven at $105^{\circ} \mathrm{C}$. The moisture content of the sludge was determined in order to measure the water found on the particle surface and in the pores.

For the thermal analysis under reducing conditions, the BOF sludge was mixed with a graphite reducing agent. The percentage of graphite added was enough to reduce the iron oxide $\left(\mathrm{Fe}_{3} \mathrm{O}_{4}\right)$ contained in the BOF sludge into metallic iron. The percentage of graphite was calculated based on the stoichiometric equations. The BF sludge contains coke, which functions as self-reducing agent.

\subsection{Analysis Methods}

The chemical composition of the BF and BOF sludges were measured using X-ray Fluorescence (XRF). About $8 \mathrm{~g}$ of the sludge was mixed with $2.6 \mathrm{~g}$ of binder (Boreox). A Panalytical Axios Max wavelength-dispersive spectrometer XRF model was used for the analysis. Carbon and sulfur contents for BF and BOF sludges were determined using a LECO CS-200. A Perkin Elmer Aanalyst 400 flame atomic absorption spectrometer (AAS) was used to measure the zinc concentrations.

The mineralogical compositions of the sludges were identified using X-ray diffraction (XRD). The XRD model used was a Rigaku SmartLab $9 \mathrm{~kW}$. The measurement conditions were $40 \mathrm{kV}$ and $135 \mathrm{~mA}$. The scanning rate was $0.02^{\circ}$ in the $2 \theta$ range of 4 to $90^{\circ}$. PDXL 2.6 software with an ICDD PDF-4 database was used for mineral identifications.

Differential thermal analysis (DTA) and thermogravimetry (TG) connected to mass spectroscopy (MS) were used to study the thermal behavior of the sludge samples. A Netzsch STA409 PC Luxx instrument was used for the thermal experiments. The experiments were carried out under air atmosphere and inert/reducing (argon) conditions. A small amount of the sample (around $30.84 \mathrm{mg}$ ) was weighed and put into a platinum crucible. The tests were carried out in the temperature range of $20-1400{ }^{\circ} \mathrm{C}$, at a heating rate of $20^{\circ} \mathrm{C} / \mathrm{min}$. At least two duplicate measurements were carried out for each experiment.

\section{Results}

\subsection{Sludge Characterization}

Figure 1 displays the $\mathrm{XRD}$ patterns of the $\mathrm{BF}$ and $\mathrm{BOF}$ sludges. The main crystalline phase of BF sludge was hematite $\left(\mathrm{Fe}_{2} \mathrm{O}_{3}\right)$ (Figure $\left.1 \mathrm{~A}\right)$. Calcite $\left(\mathrm{CaCO}_{3}\right)$, quartz $\left(\mathrm{SiO}_{2}\right)$, and minor amounts of magnetite $\left(\mathrm{Fe}_{3} \mathrm{O}_{4}\right)$ were also found in the $\mathrm{BF}$ sludge. Hematite was present in the iron ore pellets which had been fed into the blast furnace. On the other hand, the BOF sludge was dominated by magnetite $\left(\mathrm{Fe}_{3} \mathrm{O}_{4}\right)$ (Figure 1B). The XRD pattern also revealed that BOF sludge contained minor amounts of 
hematite $\left(\mathrm{Fe}_{2} \mathrm{O}_{3}\right)$, quartz $\left(\mathrm{SiO}_{2}\right)$, calcite $\left(\mathrm{CaCO}_{3}\right)$, and metallic iron $(\mathrm{Fe})$. Zinc phases were not detected due to their low concentration as well as the XRD peaks overlapping with magnetite [8].

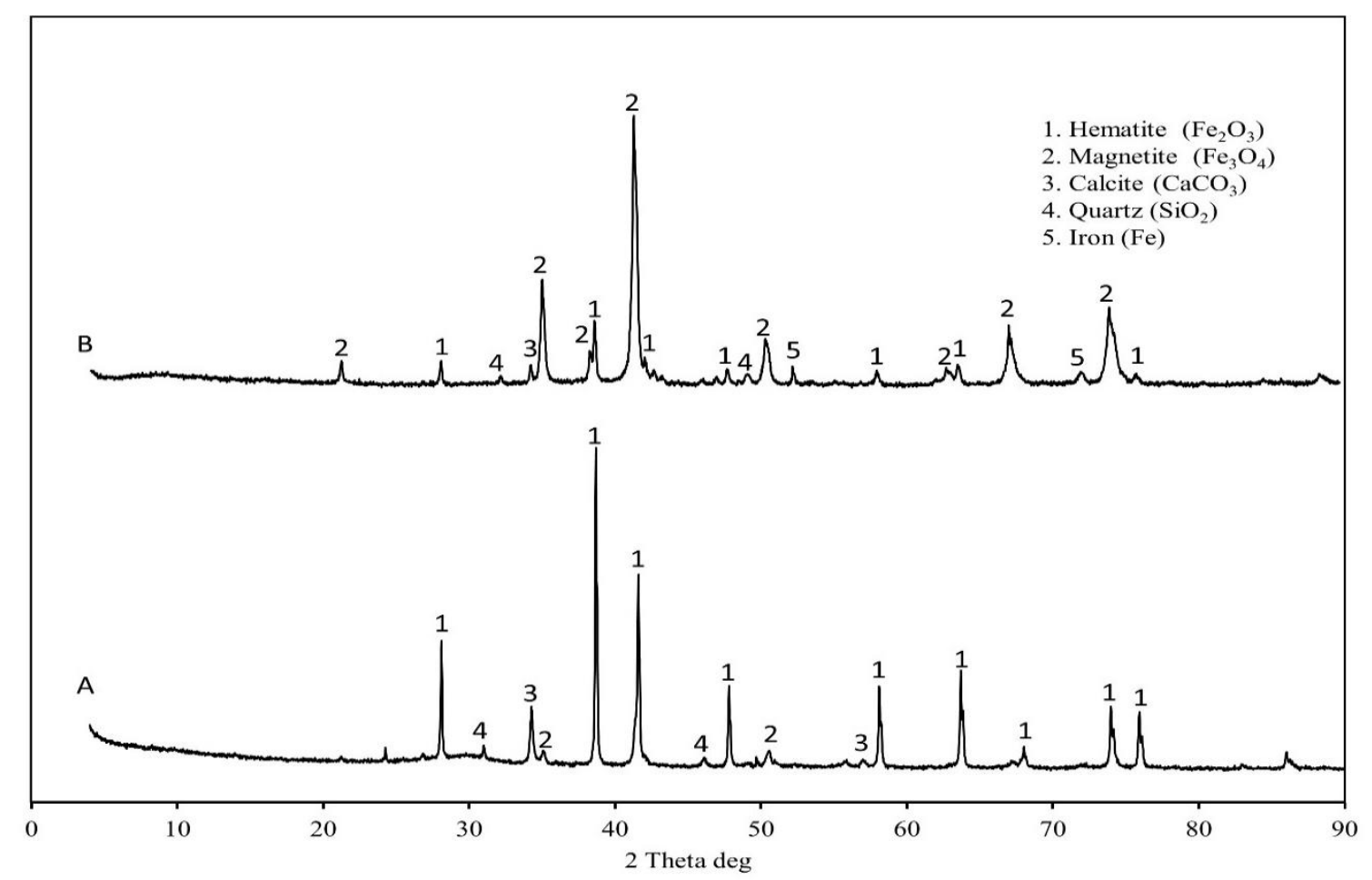

Figure 1. XRD (X-ray diffraction) patterns: (A) BF (blast furnace) sludge; (B) BOF (basic oxygen furnace) sludge.

Table 1 lists the major and minor elements of BF and BOF sludges. The moisture content in both $\mathrm{BF}$ and $\mathrm{BOF}$ sludges was about $32.5 \%$. The major elements of the BF sludge were iron oxide and carbon. The concentrations of $\mathrm{Fe}_{2} \mathrm{O}_{3}$ and $\mathrm{C}$ were 58.57 and $22.05 \mathrm{wt}$.\%, respectively. The iron and fine coke were carried away by the air blown through the blast furnace into the top gas [2]. BF sludge also contained $9.05 \mathrm{wt} . \% \mathrm{SiO}_{2}$ and $9.53 \mathrm{wt} . \% \mathrm{CaO}$ (Table 1). The $\mathrm{Zn}, \mathrm{Pb}$, and alkaline elements were found in low concentrations of $<1 \mathrm{wt} . \%$. These elements appeared due to the impurities found in the iron oxides and in the coke ash.

On the other hand, the BOF sludge was predominantly made up of iron oxide. The concentration of $\mathrm{Fe}_{2} \mathrm{O}_{3}$ was 80.79 wt.\%. The BOF sludge also contained a small amount of calcium and silica. The $\mathrm{CaO}$ and $\mathrm{SiO}_{2}$ contents were $4.25 \mathrm{wt} . \%$ and $2.04 \mathrm{wt} . \%$, respectively. The BOF contained considerable amounts of $\mathrm{ZnO}(1.36 \mathrm{wt} . \%)$. The $\mathrm{Pb}$ and alkaline element contents of $\mathrm{BOF}$ were lower, at $<1 \mathrm{wt} . \%$.

Table 1 presents the distribution of trace elements in BF and BOF sludges. Vanadium was found in high concentrations in both BOF and BF sludges. The vanadium contents in BOF and BF were 3684 and 1699 ppm, respectively. $\mathrm{Rb}, \mathrm{Ba}, \mathrm{Sr}, \mathrm{As}, \mathrm{Cs} \mathrm{Zr}$, Sn, and Sb exhibited relatively low concentrations. 
Table 1. Detailed chemical composition of BF and BOF sludges.

\begin{tabular}{|c|c|c|c|}
\hline \multirow{2}{*}{ Component } & BOFS & BFS & \multirow{2}{*}{ Analysis Technique } \\
\hline & \multicolumn{2}{|c|}{ Major Element (wt. \%) } & \\
\hline $\mathrm{Fe}_{2} \mathrm{O}_{3}$ & 80.79 & 58.57 & XRF \\
\hline $\mathrm{C}$ & 0.36 & 22.05 & Leco \\
\hline $\mathrm{CaO}$ & 4.25 & 9.53 & $\mathrm{XRF}$ \\
\hline $\mathrm{SiO}_{2}$ & 2.04 & 9.05 & XRF \\
\hline $\mathrm{MgO}$ & 1.10 & 2.54 & XRF \\
\hline $\mathrm{Al}_{2} \mathrm{O}_{3}$ & 0.18 & 3.58 & XRF \\
\hline $\mathrm{SO}_{3}$ & 0.06 & 1.46 & Leco \\
\hline \multirow[t]{2}{*}{$\mathrm{ZnO}$} & 1.36 & 0.98 & AAS \\
\hline & \multicolumn{2}{|c|}{ Minor Element (ppm) } & \\
\hline $\mathrm{NaO}$ & 3965 & 4258 & XRF \\
\hline $\mathrm{PbO}$ & 137 & 876 & XRF \\
\hline $\mathrm{K}_{2} \mathrm{O}$ & 2089 & 3740 & XRF \\
\hline $\mathrm{MnO}$ & 9470 & 1375 & XRF \\
\hline $\mathrm{P}_{2} \mathrm{O}_{5}$ & 1581 & 1523 & XRF \\
\hline $\mathrm{TiO}_{2}$ & 909 & 2126 & XRF \\
\hline $\mathrm{Ni}$ & 102 & 150 & XRF \\
\hline $\mathrm{Cu}$ & 20 & 67 & XRF \\
\hline $\mathrm{V}_{2} \mathrm{O}_{5}$ & 3684 & 1699 & XRF \\
\hline $\mathrm{Rb}$ & 104 & 143 & XRF \\
\hline $\mathrm{Sr}$ & 84 & 115 & XRF \\
\hline As & 50 & 119 & XRF \\
\hline $\mathrm{Ga}$ & 26 & 35 & XRF \\
\hline $\mathrm{Ba}$ & 130 & 184 & XRF \\
\hline Cs & 53 & 90 & XRF \\
\hline $\mathrm{Zr}$ & 19 & 20 & XRF \\
\hline $\mathrm{Sb}$ & 38 & 38 & XRF \\
\hline $\mathrm{Ce}$ & 7 & 35 & XRF \\
\hline $\mathrm{Nd}$ & 11 & 27 & XRF \\
\hline $\mathrm{Bi}$ & 14 & 30 & XRF \\
\hline
\end{tabular}

\subsection{Thermal Analysis}

\subsubsection{Under Air Atmosphere}

The thermal behavior of BF and BOF sludges as a function of temperature under both normal air atmosphere and without adding graphite was studied.

Figure 2 shows TG/DTA/DTG curves of the BF sludge as studied in air atmosphere. The process starts with moisture evaporation in the beginning, as indicated by a slight mass loss and an $\mathrm{H}_{2} \mathrm{O}$ curve of the evolved gases (Figure 2B). The wide-ranging endothermic reaction of between 324 and $440{ }^{\circ} \mathrm{C}$ is due to the elaboration of the combined water and dihydroxylation [11]. Nearly $2.22 \%$ of the BF sludge mass loss was due to the evaporation of water.

Shortly after the initial stage, at $536-659^{\circ} \mathrm{C}$, the exothermic reaction of carbon gasification and formation of $\mathrm{CO}$ and $\mathrm{CO}_{2}$ dominated the process. The two exothermic peaks at 536 and $659{ }^{\circ} \mathrm{C}$ resulted from the carbon oxidation reactions $\left(\mathrm{CO}\right.$ and $\left.\mathrm{CO}_{2}\right)$. The reactions occurred as in Equations (1)-(2) [12-14]:

At $536{ }^{\circ} \mathrm{C}$, carbon is ignited, and $\mathrm{CO}_{2}$ formation begins according to reaction (1):

$$
\mathrm{C}+\mathrm{O}_{2(\mathrm{~g})} \rightarrow \mathrm{CO}_{2(\mathrm{~g})}+394 \mathrm{~kJ}
$$

At about $659^{\circ} \mathrm{C}, \mathrm{CO}$ formation takes place according to Equation (2):

$$
2 \mathrm{C}+\mathrm{O}_{2(\mathrm{~g})} \rightarrow 2 \mathrm{CO}_{(\mathrm{g})}+221 \mathrm{~kJ}
$$




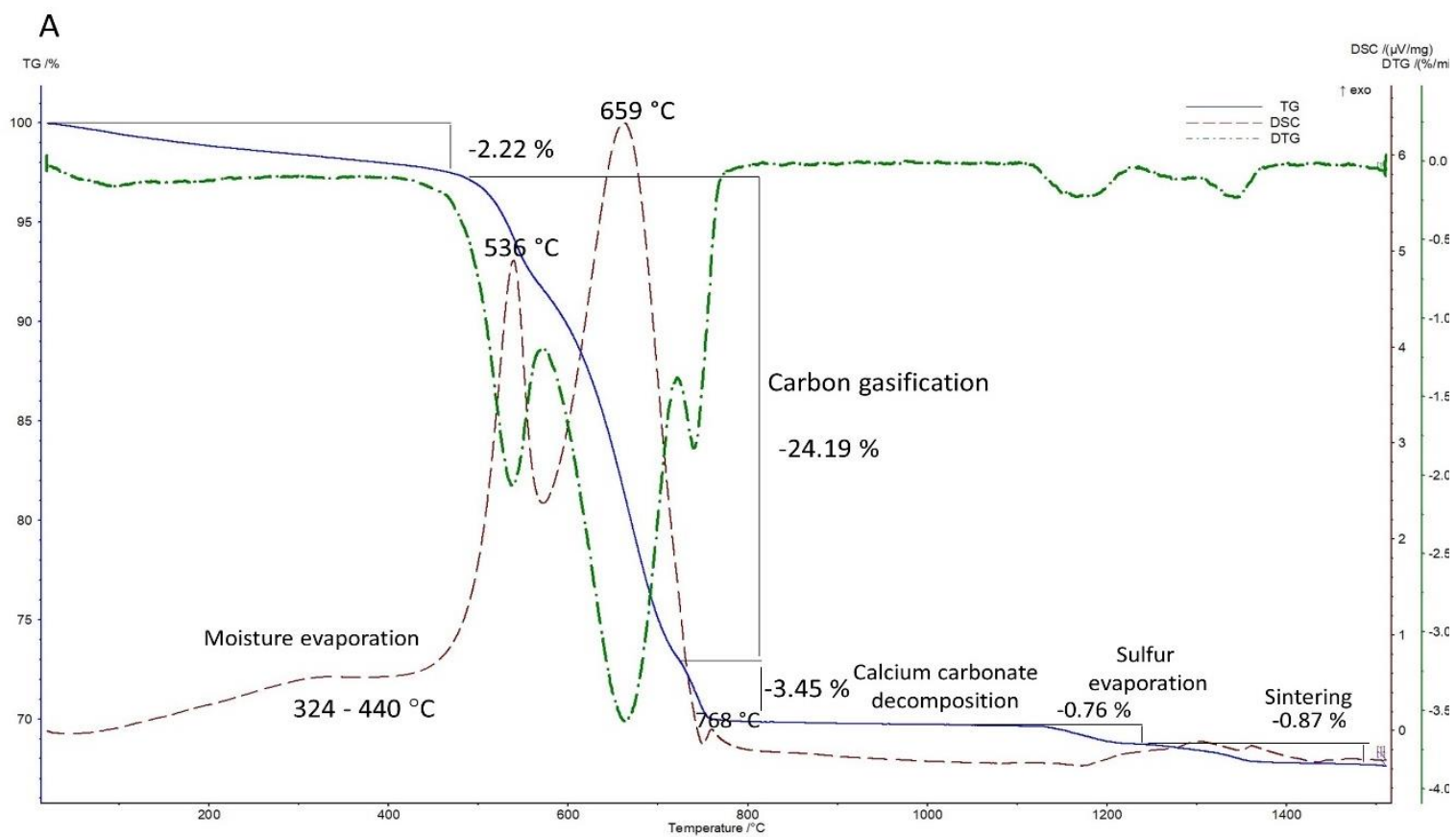

B

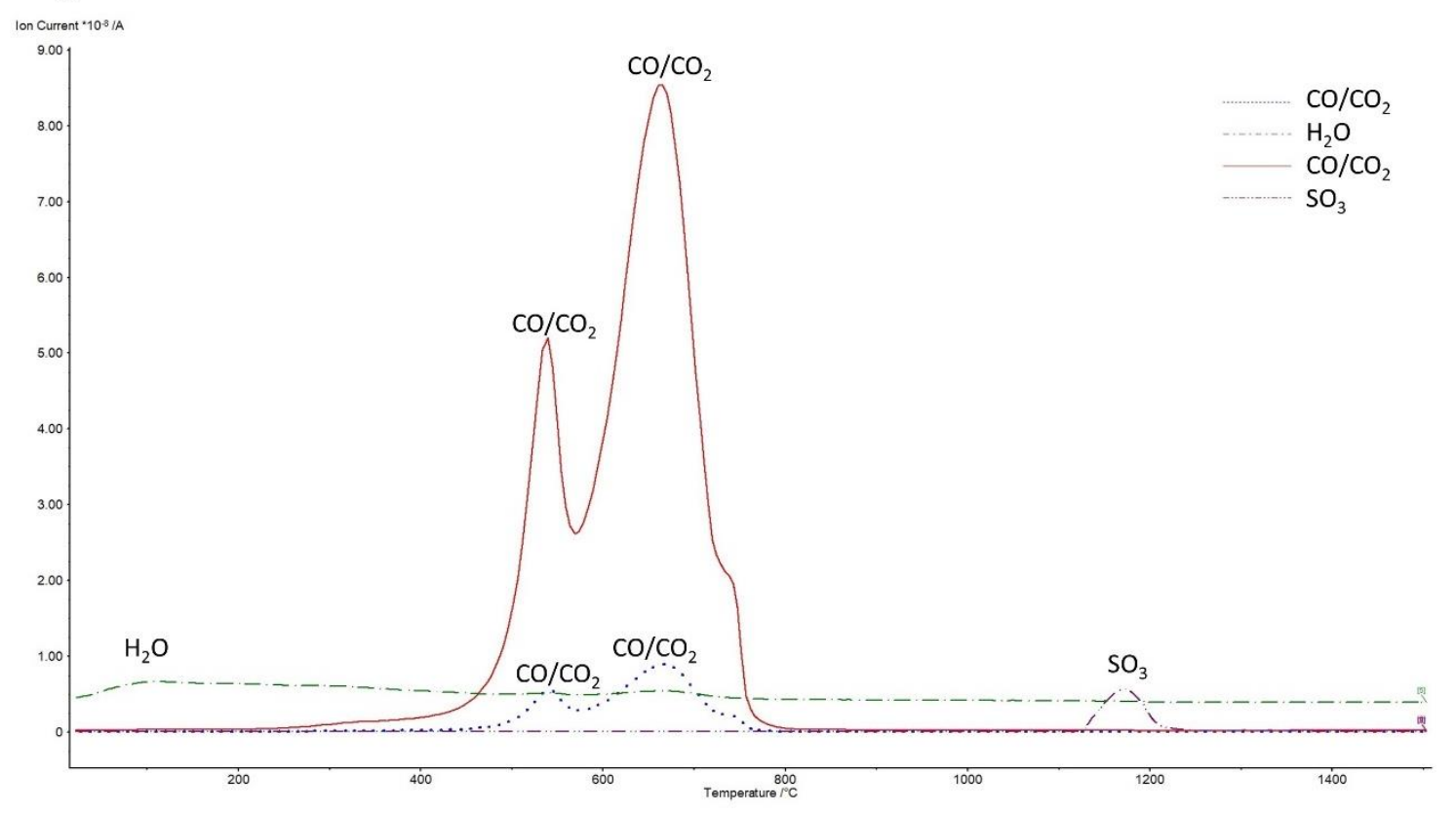

Figure 2. Thermal analysis of BF sludge under air atmosphere: (A) TG/DTA/DTG; (B) Mass spectroscopy.

The exothermic carbon gasification reaction coincided with the $\mathrm{CO} / \mathrm{CO}_{2}$ mass spectroscopy (Figure 2B). The TG curve shows a weight loss of about $24.19 \%$. This mass loss is in accordance with the carbon concentration of the BFS. The small peak at $768{ }^{\circ} \mathrm{C}$ was related to the liming of calcium carbonate $\left(\mathrm{CaCO}_{3}\right)$, which is associated with a $3.45 \%$ weight loss. At a temperature of $1173{ }^{\circ} \mathrm{C}$ the sulfur evolved from the BF sludge, owing to the decomposition of sulfur bearing compounds, as verified by the $\mathrm{S}$ spectrum curve. The sample contained about $1.46 \% \mathrm{SO}_{3}$. A mass loss was observed at $1300{ }^{\circ} \mathrm{C}$ owing to the sample sintering and the release of gases.

Figure 3 displays TG/DTA/DTG curves of BOF sludge studied in air atmosphere. The thermal behavior of BOF sludge under air atmosphere was significantly different from that of BF sludge. TG-DTA curves show three weak reactions associated with small mass loss (Figure 3A). 

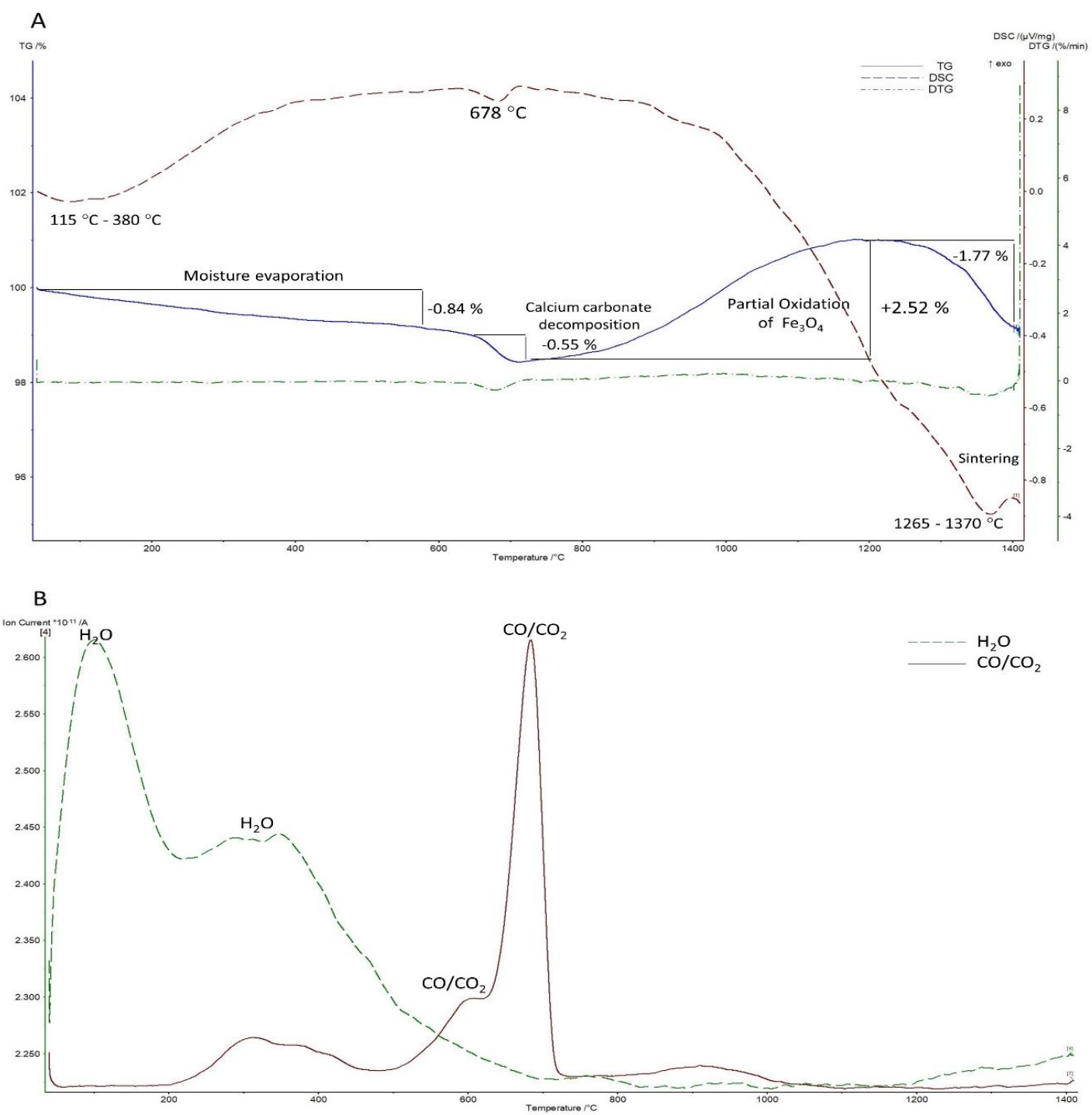

Figure 3. Thermal analysis of BOF sludge under air atmosphere: (A) TG/DTA/DTG; (B) Mass spectroscopy.

The TG curve shows a small and gradual mass loss at $115-380^{\circ} \mathrm{C}$, which reflects the moisture evaporated from the $\mathrm{BOF}$, as verified by the $\mathrm{H}_{2} \mathrm{O}$ spectrum curve (Figure $3 \mathrm{~B}$ ). About $0.84 \%$ mass loss was owed to the evolution of water. A small weight loss occurred at $678{ }^{\circ} \mathrm{C}$, owing to the residual carbonate dissociation in the sludge, as confirmed by the $\mathrm{CO}_{2}$ spectra (Figure 3B). Further, this reaction may be due to the carbon gasification $\left(\mathrm{CO}\right.$ and $\left.\mathrm{CO}_{2}\right)$. A mass gain was detected in the TG curve above $755^{\circ} \mathrm{C}(+2.52 \%)$. This is due to the oxidation of contained iron oxide to a higher oxidation state, indicated by partial conversion of $\mathrm{Fe}_{3} \mathrm{O}_{4}$ to $\mathrm{Fe}_{2} \mathrm{O}_{3}$. This mass gain did not occur when the sample was heated in an inert atmosphere.

The reaction occurred at high temperatures of between 1265 and $1370{ }^{\circ} \mathrm{C}$ owing to the sample sintering. The mass spectrum of the gas evolution pattern specifies that $\mathrm{H}_{2} \mathrm{O}$ and $\mathrm{CO}_{2}$ were the major gases evolved.

\subsubsection{Under Inert/Reducing Atmosphere (Argon Atmosphere)}

Figure 4 shows a TG/DTA/DTG diagram of BF sludge under an argon atmosphere. Under inert atmosphere the reduction of the iron oxide and formation of $\mathrm{CO}$ dominated the reaction. This is confirmed by the endothermic peaks which are synchronized with the appearance of the $\mathrm{CO} / \mathrm{CO}_{2}$ gas peak in the mass spectra. 

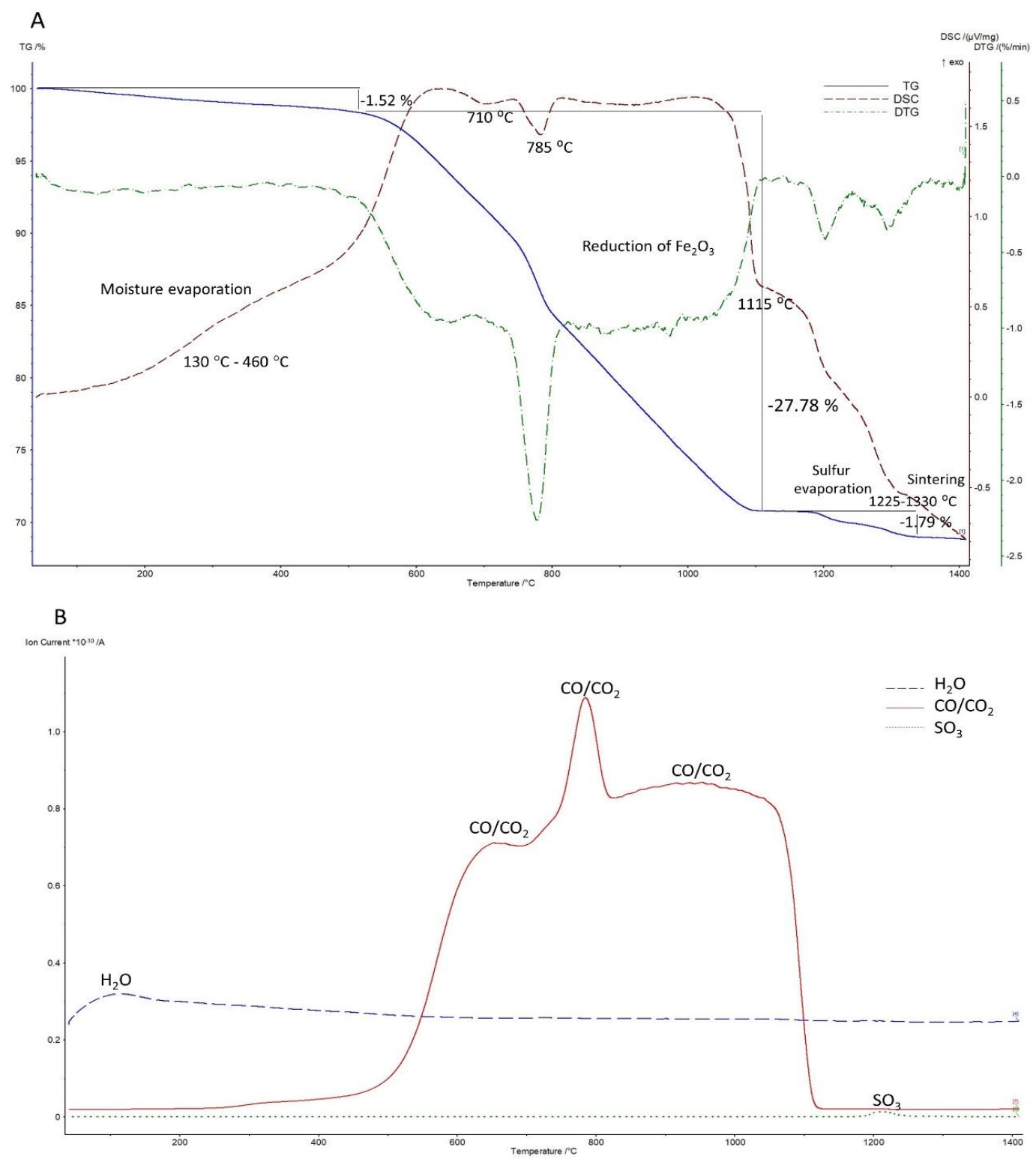

Figure 4. Thermal analysis of BF sludge under argon atmosphere: (A) TG/DTA/DTG; (B) Mass spectroscopy.

The broad endothermic peak at the early stage of heating, between 130 and $460{ }^{\circ} \mathrm{C}$, is attributable to the elimination of moisture from the sample. About $1.52 \%$ mass loss was measured due to the evaporation of water. The endothermic reactions from $710{ }^{\circ} \mathrm{C}$ to $1115^{\circ} \mathrm{C}$ are related to the reduction of hematite to metallic iron.

In the beginning, the hematite $\left(\mathrm{Fe}_{2} \mathrm{O}_{3}\right)$ reduced to magnetite $\left(\mathrm{Fe}_{3} \mathrm{O}_{4}\right)$, which was then reduced to wustite $(\mathrm{FeO})$ and finally to metallic iron (Fe). Equations (3)-(5) present the reduction reactions:

$$
\begin{gathered}
3 \mathrm{Fe}_{2} \mathrm{O}_{3(\mathrm{~s})}+\mathrm{CO}_{(\mathrm{g})}=2 \mathrm{Fe}_{3} \mathrm{O}_{4}(\mathrm{~s})+\mathrm{CO}_{2(\mathrm{~g})} \\
\mathrm{Fe}_{3} \mathrm{O}_{4(\mathrm{~s})}+\mathrm{CO}_{(\mathrm{g})}=3 \mathrm{FeO}_{(\mathrm{s})}+\mathrm{CO}_{2(\mathrm{~g})} \\
\mathrm{FeO}_{(\mathrm{s})}+\mathrm{CO}_{(\mathrm{g})}=\mathrm{Fe}_{(\mathrm{s})}+\mathrm{CO}_{2(\mathrm{~g})}
\end{gathered}
$$

The mass spectrum of gas evolution during the reaction indicates that $\mathrm{CO} / \mathrm{CO}_{2}$ were the major gases evolved in this temperature range (Figure 4B). $\mathrm{CO}$ was formed owing to the reaction between solid carbon and oxygen contained in the sludge. The nitrogen atmosphere prevented the oxidation of iron 
oxide. The weight loss is a result of oxygen released from $\mathrm{Fe}_{2} \mathrm{O}_{3}$ to form $\mathrm{CO}_{2}[14,15]$. The mass spectrum shows that the reduction of $\mathrm{Fe}^{3+}$ to $\mathrm{Fe}^{0}$ was connected with an oxygen mass loss at temperatures ranging from 710 to $1115^{\circ} \mathrm{C}$ (Figure 4B). The total mass loss of the BF sludge was about $27.78 \%$ due to the iron oxides reduction and coke oxidation.

At the same time, the peak at $710^{\circ} \mathrm{C}$ can be related to the calcination of calcium carbonate [12]. The zinc contained in the BF sludge evaporated at $785^{\circ} \mathrm{C}[16,17]$. This is consistent with the results obtained by Ökvist et al. [13]. At a temperature of $1225^{\circ} \mathrm{C}$ the sulfur evaporated from the BF sludge, as verified by the $\mathrm{S}$ spectrum curve. The reaction at $1330^{\circ} \mathrm{C}$, associated with mass loss, was due to the sample sintering.

Figure 5 shows a TG/DTA/DTG diagram of BOF sludge under argon atmosphere. Similar to BF sludge, the thermal behavior of BOF sludge was dominated by a reduction reaction. About $0.32 \%$ of weight loss was due to moisture evaporation from the BOF sludge in the early heating process.
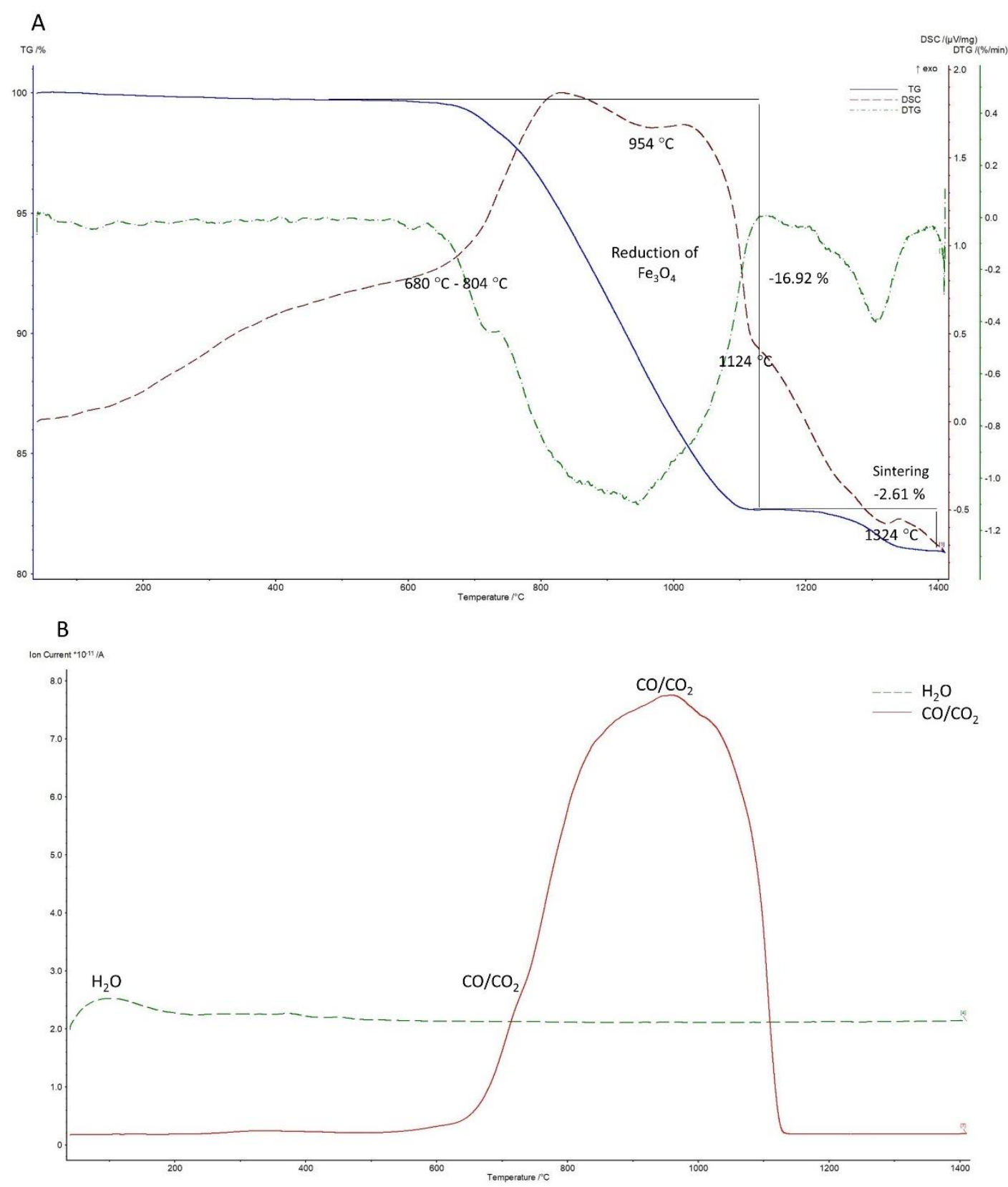

Figure 5. Thermal analysis of BOF sludge under argon atmosphere: (A) TG/DTA; (B) Mass spectroscopy. 
The endothermic reaction at $680{ }^{\circ} \mathrm{C}$ can be attributed to the liming of carbonates [12]. The endothermic reactions from 800 to $1124^{\circ} \mathrm{C}$ were related to the reduction of iron oxides. XRD results indicate that the BOF sludge was composed mainly of magnetite (Figure 1B). The reaction begins with the reduction of magnetite $\left(\mathrm{Fe}_{3} \mathrm{O}_{4}\right)$ to wustite $(\mathrm{FeO})$ and then to metallic iron $(\mathrm{Fe})$. The mass spectrum of gas evolution during the reaction indicates that the main gases detected were $\mathrm{CO} / \mathrm{CO}_{2}$. The total weight loss of BOF sludge was nearly $16.92 \%$, owing to the reduction of magnetite to iron metal.

The endothermic reaction at $800{ }^{\circ} \mathrm{C}$ was also related to $\mathrm{ZnO}$ reduction with the $\mathrm{BOF}$ sludge containing $1.36 \% \mathrm{ZnO}$ [14]. The mass spectrometry did not detect the $\mathrm{Zn}$ gas released from this reaction due to zinc deposited on the reaction tube. Mikhail and Turcotte [18] observed that zinc had been precipitated on the reaction tube after the sample was heated to $1000{ }^{\circ} \mathrm{C}$. The reaction at the high temperature of $1324^{\circ} \mathrm{C}$, associated with mass loss, was a result of the sample sintering.

\section{Conclusions}

The thermal behavior of BF and BOF sludges were examined by TG/DTA/MS. The results showed some differences in the behavior of the two sludge samples. The results are valuable in exploring the high-temperature behavior of valuable and hazardous elements in the sludges.

In the case of BF sludge, under air atmosphere the process was dominated by an exothermic carbon oxidation reaction, owing to the high carbon content of the BF sludge. At a temperature of $1173{ }^{\circ} \mathrm{C}$, the mass spectrum confirmed the evolution of sulfur from the sample. Under an inert atmosphere, a sequence of endothermic reactions from 785 to $1115^{\circ} \mathrm{C}$ corresponded to the reduction of iron oxides as follows: $\mathrm{Fe}_{2} \mathrm{O}_{3} \rightarrow \mathrm{Fe}_{3} \mathrm{O}_{4} \rightarrow \mathrm{FeO} \rightarrow$ Fe. A total mass loss of about $27.78 \%$ was observed in the TG curve.

In the case of BOF sludge, the thermal behavior of BOF sludge under air atmosphere was characterized by a mass gain at $755{ }^{\circ} \mathrm{C}$. BOF sludge was dominated by magnetite $\left(\mathrm{Fe}_{3} \mathrm{O}_{4}\right)$, which partially oxidized to $\mathrm{Fe}_{2} \mathrm{O}_{3}$. Under inert atmosphere, endothermic peaks from 800 to $1124{ }^{\circ} \mathrm{C}$ were related to the reduction of magnetite $\left(\mathrm{Fe}_{3} \mathrm{O}_{4}\right)$ to wustite $(\mathrm{FeO})$ and metallic iron $(\mathrm{Fe})$. The total weight loss of the BOF sludge was approximately $16.92 \%$.

The mass spectrum of gas evolution for both BF and BOF sludges under inert atmosphere showed that the main gases released during the reaction were $\mathrm{CO} / \mathrm{CO}_{2}$ gases.

Based on the composition and thermal behavior of the sludges, pellets are the best and most suitable way to recycle the sludges for re-use in the iron and steel industry.

Author Contributions: M.O. carried out experimental work, data analysis and writing the manuscript; T.F.; Y.Y. and G.C. participated in designing the experiments and drafting the manuscript. All authors reviewed the manuscript and agreed to its publication. All authors have read and agreed to the published version of the manuscript.

Funding: This work was conducted within the Symbiosis of Metal Production and Nature (SYMMET) research program funded by Business Finland.

Acknowledgments: The authors acknowledge Olli Mattila and Timo Paananen from SSAB Europe for their comments and for offering samples. A special thanks to Riku Mattila and Tommi Kokkonen for their technical support throughout this work.

Conflicts of Interest: The authors declare no conflicts of interest.

\section{References}

1. Machado, J.G.; Brehm, F.A.; Moraes, C.A.; Santos, C.A.; Vilela, A.C.; Cunha, J.B. Chemical, physical, structural and morphological characterization of the electric arc furnace dust. J. Hazard. Mater. 2006, 136, 953-960. [CrossRef] [PubMed]

2. Mansfeldt, T.; Dohrmann, R. Chemical and mineralogical characterization of blast furnace sludge from an abandoned landfill. Environ. Sci. Technol. 2004, 38, 5977-5984. [CrossRef] [PubMed]

3. Szekely, J. A Research Program for the Minimization and Effective Utilization of Steel Plant Wastes. Iron Steelmak. 1995, 22, 25-29. 
4. Trung, Z.H.; Kukurugya, F.; Takacova, Z.; Orac, D.; Laubertova, M.; Miskufova, A.; Havlik, T. Acidic Leaching Both of Zinc and Iron from Basic Oxygen Furnace Sludge. J. Hazard. Mater. 2011, 192, 1100-1107. [CrossRef] [PubMed]

5. Van Herck, P.; Vandecasteele, C.; Swennen, R.; Mortier, R. Zinc and Lead Removal from Blast Furnace Sludge with a Hydrometallurgical Process. Environ. Sci. Technol. 2000, 34, 3802-3808. [CrossRef]

6. Kretzschmar, R.; Mansfeldt, T.; Mandaliev, P.N.; Barmettler, K.; Marcus, M.A.; Voegelin, A. Speciation of Zn in Blast Furnace Sludge from Former Sedimentation Ponds Using Synchrotron X-ray Diffraction, Fluorescence, and Absorption Spectroscopy. Environ. Sci. Technol. 2012, 46, 12381-12390. [CrossRef] [PubMed]

7. Wang, C.; Jennes, R.; Mattila, O.; Paananen, T.; Lilja, J.; Larsson, M. Investigation of Applying OxyCup ${ }^{\circledR}$ Process for an Integrated Steel Plant from a Nordic Country. In Proceedings of the METEC \& 2nd European Steel Application Days (ESTAD), Dusseldorf, Germany, 15-19 June 2015; pp. 1-5.

8. Omran, M.; Fabritius, T.; Paananen, T. Effect of blast furnace sludge (BFS) characteristics on suitable recycling process determining. JMMCE 2017, 5, 185-197. [CrossRef]

9. Mansfeldt, T.; Dohrmann, R. Identification of a Crystalline Cyanide- Containing Compound in Blast-Furnace Sludge Deposits. J. Environ. Qual. 2001, 30, 1927-1932. [CrossRef] [PubMed]

10. Foldi, C.; Dohrmann, R.; Mansfeldt, T. Mercury in Dumped Blast Furnace Sludge. Chemosphere 2014, 99, 248-253. [CrossRef] [PubMed]

11. Salama, W.; El Aref, M.; Gaupp, R. Spectroscopic characterization of iron ores formed in different geological environments using FTIR, XPS, Mössbauer spectroscopy and thermoanalyses. Spectrochim. Acta Mol. Biomol. Spectrosc. 2015, 136, 1816-1826. [CrossRef] [PubMed]

12. Mombelli, D.; Di Cecca, C.; Mapelli, C.; Barella, S.; Bondi, E. Experimental analysis on the use of BF-sludge for the reduction of BOF-powders to direct reduced iron (DRI) production. Process Saf. Environ. Prot. 2016, 102, 410-420. [CrossRef]

13. Ökvist, L.S.; Cang, D.; Zong, Y.; Bai, H. The effect of BOF slag and BF flue dust on coal combustion efficiency. ISIJ Int. 2004, 44, 1501-1510. [CrossRef]

14. Omran, M.; Fabritius, T. Improved removal of zinc from blast furnace sludge by particle size separation and microwave heating. Miner. Engin. 2018, 127, 265-276. [CrossRef]

15. Monazam, E.R.; Breault, R.W.; Siriwardane, R. Reduction of hematite $\left(\mathrm{Fe}_{2} \mathrm{O}_{3}\right)$ to wüstite (FeO) by carbon monoxide (CO) for chemical looping combustion. Chem. Eng. J. 2014, 242, 204-210. [CrossRef]

16. Oustadakis, P.; Tsakiridis, P.E.; Katsiapi, A.; Leonardou, S.A. Hydrometallurgical process for zinc recovery from electric arc furnace dust (EAFD) Part I: Characterization and leaching by diluted sulphuric acid. J. Hazard. Mater. 2010, 179, 1-7. [CrossRef] [PubMed]

17. Omran, M.; Fabritius, T. Treatment of blast furnace sludge (BFS) using a microwave heating technique. Ironmak. Steelmak. 2017, 44, 619-629. [CrossRef]

18. Mikhail, S.A.; Turcotte, A.-M. Thermal reduction of steel-making secondary materials I. Basic-oxygen-furnace dust. Thermochim. Acta 1998, 311, 113-119. [CrossRef]

(C) 2020 by the authors. Licensee MDPI, Basel, Switzerland. This article is an open access article distributed under the terms and conditions of the Creative Commons Attribution (CC BY) license (http://creativecommons.org/licenses/by/4.0/). 